\title{
KONDISI KARANG SCLERACTINIA DI PERAIRAN BULUTUI KECAMATAN LIKUPANG BARAT KABUPATEN MINAHASA UTARA
}

\author{
(THE CONDITION OF SCLERACTINIA CORAL AT BULUTUI WATERS, WEST LIKUPANG \\ SUBDISTRICT, NORTH MINAHASA DISTRICT)
}

\author{
M. Takdir Umanailo, Indri S. Manembu, Hermanto W.K. Manengkey, Carolus P. Paruntu, \\ Rosita A. J. Lintang, Wilmy E. Pelle \\ Program Studi IImu Kelautan FPIK UNSRAT Manado \\ *e-mail: indrimanembu@gmail.com
}

\begin{abstract}
Hard coral is one of the main components of this forming coral reef ecosystem. Bulutui waters have coral reef ecosystems that have a direct role as a source of livelihood for people around these waters. However, there are non-environmentally friendly human activities such as fishing using explosives or chemical solutions that cause coral reef damage. The aimed of this research was to find out the condition of hard coral's percentage cover and to described the frequency of hard coral's occurance therefore it's could be representative data at this location. Coral data was collected by using PIT (Point Intercept Transect) method. The value of percentage cover of hard corals at Bulutui waters are $20.58 \%$ and the value is categorized damaged. The total frequency of hard coral's occurance at station 1 are 66 and dominated by Coral Submassive (CS), at station 2 are 23 and dominated by Coral Massive (CM), at station 3 are 18 and dominated by Coral Foliose (CF) and then at station 4 are 140 and dominated by Coral Foliose (CF).
\end{abstract}

Keywords: Percentage Cover, Scleractinia Coral, Bulutui Waters, PIT Methods.

Karang keras merupakan salah satu komponen utama penyusun ekosistem terumbu karang. Perairan Bulutui memiliki ekosistem terumbu karang yang mempunyai peranan secara langsung sebagai sumber mata pencaharian masyarakat di sekitar perairan tersebut. Akan tetapi, adanya aktivitas manusia yang tidak ramah lingkungan seperti penangkapan ikan menggunakan bahan peledak atau larutan kimia yang menyebabkan kerusakan terumbu karang. Penelitian ini bertujuan untuk mengetahui persentase kondisi tutupan karang keras dan untuk mendeskripsikan frekuensi karang keras sehingga dapat menjadi data yang representatif pada lokasi ini. Pengumpulan data karang menggunakan metode PIT (Point Intercept Transect). Nilai persentase tutupan karang keras di perairan Bulutui adalah $20,58 \%$ dan nilai tersebut berada pada kategori buruk. Total frekuensi kemunculan karang pada stasiun I sebanyak 66 kali dan didominasi oleh Coral Submassive (CS), Pada stasiun II total frekuensi kemunculan karang sebanyak 23 kali dan didominasi oleh Coral massive (CM), pada stasiun III total frekuensi kemunculan karang sebanyak 18 kali dan didominasi oleh Coral Foliose (CF) dan selanjutnya pada stasiun IV total frekuensi kemunculan karang sebanyak 140 kali dan didominasi oleh Coral Foliose (CF).

Kata Kunci: Persentase Tutupan, Karang Scleractinia, Perairan Bulutui, Metode PIT. 


\section{PENDAHULUAN}

Karang keras merupakan salah satu komponen penyusun ekosistem terumbu karang. Ekosistem terumbu karang memiliki peranan yang sangat besar. Secara langsung ekosistem ini berperan sebagai obyek wisata bahari, sarana pendidikan dan penelitian, serta farmasi. Sedangkan peranan terumbu karang secara tidak langsung yaitu sebagai pelindung pantai dari degradasi dan abrasi, pemecah gelombang, sumber keanekaragaman hayati dan merupakan sumber plasma nutfah (Haris, 2008).

Provinsi Sulawesi Utara merupakan salah satu provinsi di Indonesia yang masuk dalam pusat Segitiga Terumbu Karang (Coral triangle) dunia dan eko-region laut Sulu-Sulawesi (Wilson et al., 2009). Berdasarkan data Hadi (2020), kondisi tutupan karang yang tercatat dari 3 stasiun di Sulawesi Utara khususnya Minahasa Utara, terdapat 2 stasiun yang masuk dalam kategori baik dan 1 stasiun dalam kategori buruk. Luasan kawasan konservasi pada provinsi Sulawesi Utara sebesar 106.930 Ha dimana Minahasa Utara masuk dalam pencadangan Kawasan Konservasi Perairan Daerah (KKPD) dengan luas sebesar 32.252,29 Ha (Kambong et al., 2013).

Perairan Bulutui merupakan salah satu perairan yang ada di Minahasa Utara. Perairan ini memiliki ekosistem terumbu karang yang berperan sebagai sumber mata pencaharian masyarakat disekitar perairan tersebut. Namun, adanya aktivitas manusia yang tidak ramah lingkungan seperti penangkapan ikan menggunakan bahan peledak atau larutan kimia menyebabkan kerusakan terumbu karang. Sehingga perlu dilakukan penelitian terkait penilaian kondisi tutupan karang batu pada lokasi ini untuk mendapatkan data yang representatif di perairan Bulutui Kabupaten Minahasa Utara.

Tujuan penelitian ini yaitu untuk mengetahui persentase kondisi tutupan karang batu dan mendeskripsikan frekuensi kemunculan karang batu di perairan Bulutui Kabupaten Minahasa Utara di perairan Bulutui Kabupaten Minahasa Utara.

\section{METODE PENELITIAN}

\section{Waktu dan Tempat Penelitian}

Penelitian ini dilaksanakan pada tanggal 18 Oktober - 30 Desember 2019. Lokasi pengambilan data yaitu berada di perairan Bulutui Kabupaten Minahasa Utara Provinsi Sulawesi Utara. Peta lokasi tersebut sebagaimana terlihat pada Gambar 1 berikut ini.

\section{Alat dan Bahan}

Alat yang digunakan dalam penelitian ini adalah peralatan scuba diving, GPS, kertas sabak, pensil, meteran, buku identifikasi karang, perahu bermotor, kamera/kamera bawah air, laptop/aplikasi Microsoft excel. Bahan yang digunakan pada penelitian adalah sampel jenis-jenis terumbu karang yang ada di perairan Bulutui Kecamatan Likupang Barat Kabupaten Minahasa Utara.

\section{Teknik Pengumpulan Data}

Pengumpulan data karang
menggunakan metode PIT (Point
Intercept Transek) (Hill \& Wilkinson,
2004). Posisi pengambilan data
ditentukan dengan menggunakan GPS
pada kedalaman 5 dan 7 meter. Meteran
sepanjang 50 meter diletakkan di dasar,
ditentukan atau diikatkan pada titik nol
(awal). Tiap bentik (karang batu, karang
mati, biota dan abiotik) yang berada
dibawah tali meteran transek dicatat mulai
dari titik 1 sampai ke titik 100 , pencatatan
tiap stasiun dilakukan tiga kali ulangan
dengan kode pencatatan dapat dilihat
dalam Tabel 2 .
menggunakan metode PIT (Point Intercept Transek) (Hill \& Wilkinson, 2004). Posisi pengambilan data ditentukan dengan menggunakan GPS pada kedalaman 5 dan 7 meter. Meteran sepanjang 50 meter diletakkan di dasar, ditentukan atau diikatkan pada titik nol (awal). Tiap bentik (karang batu, karang mati, biota dan abiotik) yang berada dari titik 1 sampai ke titik 100, pencatatan tiap stasiun dilakukan tiga kali ulangan dalam Tabel 2. 
Tabel 1. Titik Koordinat Pengambilan Data

\begin{tabular}{|c|c|c|}
\hline Stasiun & \multicolumn{2}{|c|}{ Koordinat } \\
\hline 1 & $\begin{array}{c}1^{\circ} 42.801^{\prime} \\
\text { LU }\end{array}$ & $\begin{array}{c}125^{\circ} 2.097^{\prime} \\
\mathrm{BT}\end{array}$ \\
\hline 2 & $1^{\circ} 42.680^{\prime}$ & $125^{\circ} 1.982^{\prime}$ \\
$\mathrm{LU}$ & $\mathrm{BT}$ \\
\hline 3 & $1^{\circ} 42.805^{\prime}$ & $125^{\circ} 1.898^{\prime}$ \\
& $\mathrm{LU}$ & $\mathrm{BT}$ \\
\hline 4 & $\begin{array}{c}1^{\circ} 42.721^{\prime} \\
\mathrm{LU}\end{array}$ & $\begin{array}{c}125^{\circ} 1.771^{\prime} \\
\mathrm{BT}\end{array}$ \\
\hline
\end{tabular}

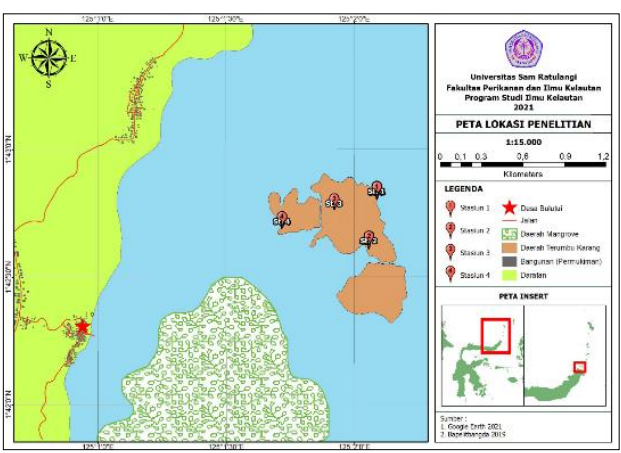

Gambar 1. Peta Lokasi Penelitian

Tabel 2. Kode Pencatatan Data Pada Transek Dalam Kegiatan Penelitian

\begin{tabular}{|l|l|l|}
\hline Kode & $\begin{array}{l}\text { Kategori } \\
\text { Biota }\end{array}$ & Keterangan \\
\hline AC & Acropra & $\begin{array}{l}\text { Karang } \\
\text { Acropora }\end{array}$ \\
\hline NA & $\begin{array}{l}\text { Non- } \\
\text { Acropora }\end{array}$ & $\begin{array}{l}\text { Karnag Non- } \\
\text { Acropora }\end{array}$ \\
\hline DC & $\begin{array}{l}\text { Death } \\
\text { Coral }\end{array}$ & $\begin{array}{l}\text { Karang mati } \\
\text { masih } \\
\text { berwarna putih }\end{array}$ \\
\hline DCA & $\begin{array}{l}\text { Death } \\
\text { Coral } \\
\text { Algae }\end{array}$ & $\begin{array}{l}\text { Karang mati } \\
\text { yang ditumbuhi } \\
\text { alga filamen }\end{array}$ \\
\hline SC & $\begin{array}{l}\text { Soft Coral } \\
\text { Jenis-jenis } \\
\text { Karang Lunak }\end{array}$ \\
\hline FS & $\begin{array}{l}\text { Fleshy } \\
\text { Seaweed }\end{array}$ & $\begin{array}{l}\text { Jenis-jenis } \\
\text { makroalga }\end{array}$ \\
\hline R & Rubble & $\begin{array}{l}\text { Patahan } \\
\text { karang } \\
\text { bercabang } \\
\text { (mati) }\end{array}$ \\
\hline S & Sand & Pasir \\
\hline
\end{tabular}

\section{Analisis Data}

Jumlah kategori bentik karang batu, karang mati, biota lain dan abiotik yang telah dicatat kemudian dikelompokkan dan dihitung sebagai persentase tutupan (\%) dengan menggunakan rumus (Hill dan Wilkinson, 2004), sebagai berikut:

$\% H C=\frac{\text { (Jumlah tiap life form }}{300 \text { (total titik) }} \times 100$

Keterangan :

$\mathrm{HC}$ : Karang Batu

Dari hasil rumus diatas, rata-rata persentase karang batu hidup di Perairan Bulutui dihitung menggunakan rumus (Manuputty dan Djuwariah, 2009), sebagai berikut:

Keterangan :

$$
\% \bar{X} H C=\frac{\mathrm{St} 1+\mathrm{St} 2+\mathrm{St} 3+\mathrm{St} 4}{4 \text { (total stasiun) }}
$$

$\mathrm{HC}$ : Karang batu

St : Stasiun

$$
\bar{X} \text { : Rata-rata }
$$

Tabel 3. Kriteria Penutupan Karang Hidup

\begin{tabular}{|c|c|c|}
\hline \multicolumn{2}{|c|}{ Kondisi } & \% Tutupan \\
\hline Rusak & Buruk & $0-24,9$ \\
\cline { 2 - 3 } & Sedang & $25-49,9$ \\
\hline Baik & Baik & $50-74,9$ \\
\cline { 2 - 3 } & $\begin{array}{c}\text { Baik } \\
\text { Sekali }\end{array}$ & $75-100$ \\
\hline
\end{tabular}

\section{HASIL DAN PEMBAHASAN}

\section{Gambaran Umum Lokasi}

Komponen penyusun ekosistem terumbu karang yang ditemukan di perairan Bulutui terdiri dari komponen biotik dan komponen abiotic Komponen biotik terdiri dari Acropora, Non Acropora dan fauna lain sedangkan komponen abiotik terdiri dari karang mati, pasir dan patahan karang. Tipe terumbu karang pada lokasi pengamatan adalah Barrier Reef atau masyarakat setempat menyebutnya dengan sebutan Napo Ila. Perairan Bulutui atau Napo lla banyak 
dipengaruhi oleh aktivitas masyarakat nelayan.

\section{Persentase Kondisi Tutupan Life Form Karang Keras}

Hasil pengamatan yang dilakukan untuk mengetahui kondisi terumbu karang pada keempat stasiun pengamatan dengan melihat bentuk pertumbuhan menggunakan metode PIT (Point Intercept Transek) berdasarkan kategori bentuk pertumbuhan (lifeform) karang yakni karang keras terdiri dari: Acropora Branching (ACB), Acropora Submasive (ACS), Acropora Tabulate (ACT), Acropora Digitate (ACD), Coral Branching (CB), Coral Massive (CM), Coral Encrusting (CE), Coral Submassive (CS), Coral Foliose (CF), Coral Musroom (CMR). Karang mati terdiri dari: Dead Coral Algae (DCA). Biota lain terdiri dari: Soft Coral (SC), Sponge (SP), Fleshy seawed (FS). Abiotik terdiri dari: Rubble (R) dan Sand (S). Kondisi terumbu karang dapat dilihat Gambar 2 di bawah ini:

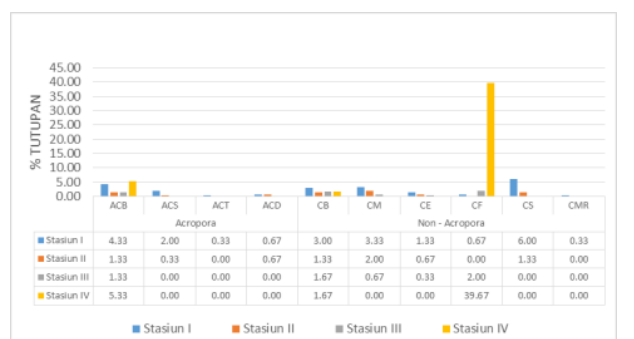

Gambar 2. Persentase Life Form Karang Keras

\section{Persentase Tutupan Karang Keras}

Berdasarkan hasil pengamatan pada lokasi penilitian, persentase kondisi terumbu karang yang di hitung menggunakan rumus dari (Hill dan Wilkinson, 2004) yaitu pada stasiun 4 memiliki persentase tutupan karang batu yang paling tinggi dengan persentase $46,67 \%$ selanjutnya pada stasiun 1 dengan persentase $22,00 \%$. Pada stasiun 2 dengan persentase $7,67 \%$ dan yang paling rendah pada stasiun 3 memiliki persentase tutupan yang paling rendah dengan persentase 6,00\% (Gambar 3).
Hasil perhitungan rata-rata karang keras perairan Bulutui di seluruh stasiun adalah $20,58 \%$. Hal tersebut bila ditinjau dari Keputusan Menteri Lingkungan Hidup Nomor 4 Tahun 2001, tentang kriteria baku kerusakan terumbu karang maka berdasarkan ketentuan tersebut, kondisi terumbu karang di perairan Bulutui tergolong dalam kondisi rusak.

Kerusakan terumbu karang sebagian besar ditimbulkan oleh kegiatan manusia (Harborne et al., 2001) seperti penggunaan bom yang menyebabkan banyaknya karang patah (rubble) sedangkan penggunaan zat bius memungkinkan terjadinya coral bleaching (pemutihan karang) (Manembu et al., 2012). Selain itu adanya aktivitas penambangan terumbu karang menyebabkan banyaknya patahan karang dan mendorong terjadinya erosi pantai yang dapat menyebabkan hilangnya pelindung pantai (Manengkey, 2010).

\section{Persentase Tutupan Karang Mati}

Persentase tutupan karang mati tertinggi terdapat pada stasiun 3 yaitu sebesar 24,67\%, selanjutnya pada stasiun 2 sebesar $18,66 \%$, kemudian stasiun 1 sebesar $17,00 \%$ dan terakhir persentase tutupan karang mati terendah ada pada stasiun 4 dengan persentase $10,00 \%$ (Gambar 3). Komponen karang mati yang terdapat di seluruh stasiun yaitu DCA (Dea coral algae). DCA (Dead coral algae) merupakan karang yang telah ditumbuhi alga lain dan lumut disebabkan karena karang telah kehilangan zooxanthellae pada fauna dan koloni karang. Kondisi tersebut akan menyebabkan karang mengalami pemutihan (Coral bleaching).

Persentase penutupan karang yang telah ditumbuhi alga (DCA) lebih besar dapat memicu pertumbuhan alga yang sangat pesat serta tingkat kecerahan yang kurang dapat menghambat pertumbuhan karang keras, di daerah ini juga menunjukkan bahwa kematian karang terjadi pada waktu yang telah lama sehingga alga sudah dapat beradaptasi 
pada tipe subtrat karang mati (Jameson et al., 1990).

\section{Persentase Tutupan Biota Lain}

Persentase tutupan kategori biota lain tertinggi ada pada stasiun 4 dengan persentase $37,67 \%$, selanjutnya stasiun 2 sebesar $26,67 \%$. Kemudian stasiun 1 sebesar $25,00 \%$ dan persentase terendah terdapat pada stasiun 3 yaitu sebesar $24,00 \%$ (Gambar 3). Persentase tutupan soft coral tertinggi ada pada stasiun 4 dengan persentase $35,67 \%$, selanjutnya stasiun 2 24,33\%, kemudian stasiun 1 sebesar $21,33 \%$ dan stasiun 3 sebesar $18,67 \%$. Persentase tutupan sponge hanya ditemukan di 2 stasiun yakni stasiun 1 dengan persentase $0,33 \%$ dan stasiun 3 sebesar $0,33 \%$. Persentase tutupan other fauna paling tinggi ada pada stasiun 3 dengan persentase 2,33\%, selanjutnya stasiun 1 , stasiun 2 dan stasiun 4 memiliki persentase yang sama yaitu $0,67 \%$. Persentase tutupan fleshy seawed tertinggi ada pada stasiun 1 , stasiun 2 dan stasiun 3 dengan persentase $2,67 \%$, kemudian pada stasiun 4 dengan persentase $1,33 \%$.

\section{Persentase Tutupan Abiotik}

Persentase tutupan abiotik tertinggi ada pada stasiun 2 dengan persentase $46,00 \%$ selanjutnya stasiun 3 sebesar $45,33 \%$. Kemudian stasiun 1 sebesar $36,00 \%$ dan persentase tutupan abiotik terendah ada pada stasiun 4 dengan persentase $5,66 \%$. Persentase sand tertinggi ada pada stasiun 3 dengan persentase $32,33 \%$ selanjutnya stasiun 2 sebesar $12,67 \%$. Kemudian stasiun 1 sebesar $12,33 \%$ dan persentase sand terendah ada pada stasiun 4 dengan persentase $3,00 \%$. Persentase rubble mulai tertinggi sampai terendah secara berturut-turut yaitu stasiun 2 dengan persentase $33,33 \%$, stasiun 1 sebesar $23,67 \%$, stasiun 3 sebesar $13,00 \%$ dan persentase rubble terendah ada pada stasiun 4 dengan persentase 2,67\% (Gambar 3).

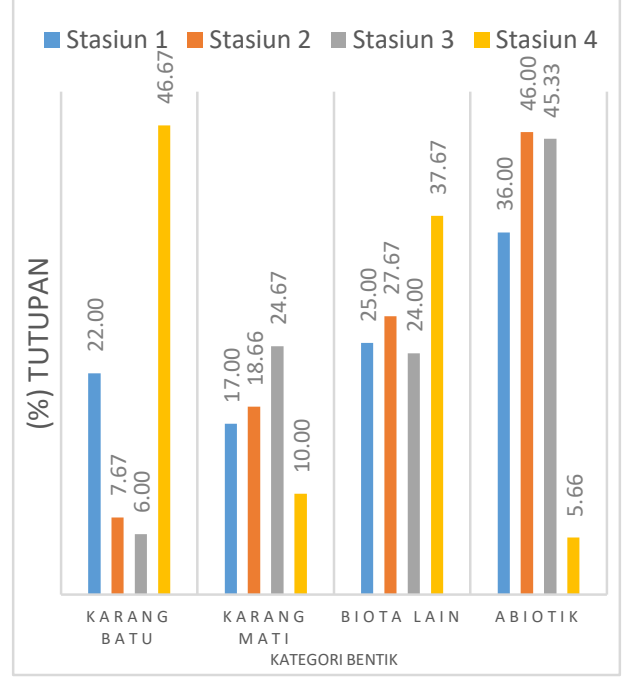

Gambar 3. Persentase Tutupan Terumbu Karang

\section{Frekuensi Kemunculan Karang Keras}

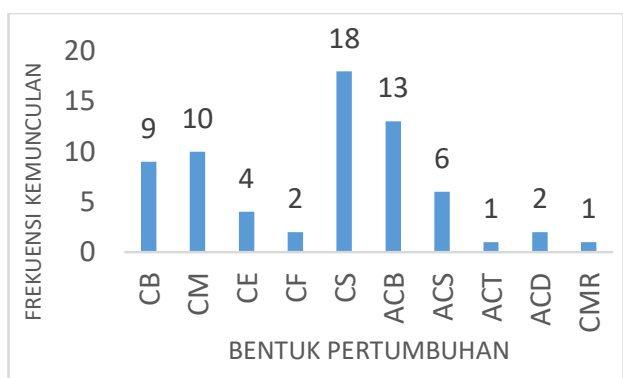

Gambar 4. Frekuensi Kemunculan Karang Keras Pada Stasiun I

Berdasarkan hasil dari pengamatan pada lokasi penelitian, frekuensi kemunculan karang keras yang ditemukan di tiap stasiun yaitu, pada stasiun I karang batu dengan lifeform Acropora branching (ACB) 13 kali kemunculan, Acropora submassive (ACS) 6 kali kemunculan, Acropora tabulate (ACT) 1 kali kemunculan dan Acropora Digitate (ACD) 2 kali kemunculan. Kemudian pada karang Non Acropora yang ditemukan pada stasiun I yaitu, coral encrusting (CE) 4 kali kemunculan, coral massive (CM) 10 kali kemunculan, coral branching (CB) 9 kali kemunculan, coral foliose (CF) 2 kali kemunculan, Coral Submassive (CS) 18 kali kemunculan dan coral mushroom (CMR) 1 kali kemunculan 
(Gambar 4). Pada stasiun I total frekuensi kemunculan karang keras sebanyak 66 kali dan pada stasiun I lebih didominasi oleh coral submassive (CS).

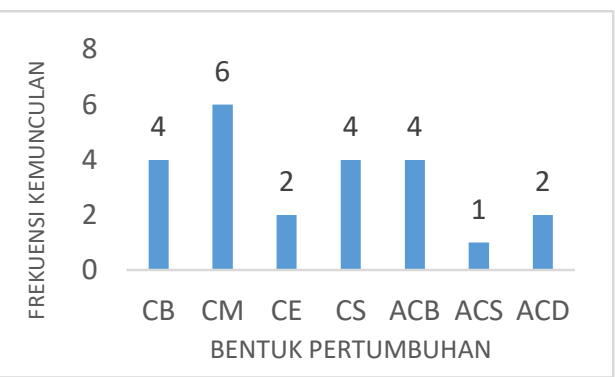

Gambar 5. Frekuensi Kemunculan Karang Keras Pada Stasiun II

Pada stasiun II frekuensi
kemunculan karang keras yang ditemukan pada kategori Acropora yaitu Acropora digitate (ACD) 2 kali kemunculan, Acropora submasive (ACS) 1 kali kemunculan dan Acropora branching (ACB) 4 kali kemunculan. Kemudian pada karang non Acropora yaitu, coral encrusting (CE) 2 kali kemunculan, coral massive (CM) 6 kali kemunculan, coral branching (CB) 4 kali kemunculan dan coral submassive (CS) 4 kali kemunculan (Gambar 5). Pada stasiun II total frekuensi kemunculan karang keras sebanyak 23 dan didominasi oleh coral massive (CM).

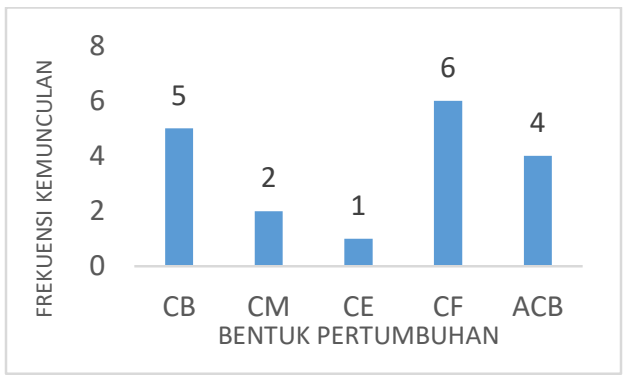

\footnotetext{
Gambar 6. Frekuensi Kemunculan Karang Keras Pada Stasiun III Pada stasiun III frekuensi kemunculan karang keras yang ditemukan pada kategori Acropora hanya Acropora branching (ACB) dengan frekuensi kemunculan 4 kali. Kemudian pada karang non Acropora yaitu, Coral Encrusting (CE) 1 kali kemunculan, Coral Massive (CM) 2 kali kemunculan, Coral
}

Branching (CB) 5 kali kemunculan dan Coral Foliose (CF) 6 kali kemunculan (Gambar 6). Pada stasiun III total frekuensi kemunculan karang keras sebanyak 18 dan didominasi oleh Coral Foliose (CF).

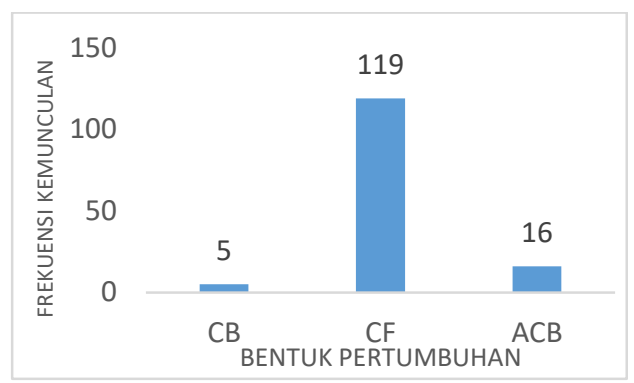

Gambar 7. Frekuensi Kemunculan Karang Keras Pada Stasiun IV

Pada stasiun IV frekuensi kemunculan karang keras yang pada kategori Acropora hanya ditemukan Acropora Submasive (ACS) dengan frekuensi kemunculan 16 kali. Kemudian pada karang non Acropora yaitu, coral branching (CB) 5 kali kemunculan dan coral foliose (CF) 119 kali kemunculan (Gambar 7). Pada stasiun IV jumlah freuensi kemunculan karang keras sebanyak 140 , lebih didominasi oleh coral Foliose (CF). menurut Luthfi dan Nurmalasari (2017) karang foliose memiliki pertumbuhan koloni terutama ke arah horizontal, dengan bentuk lembaran yang pipih. Menurut Suharsono (1984), karang Acropora merupakan karang keras fast growth species (spesies dengan kecepatan pertumbuhan tinggi) yang pertumbuhannya mencapai $15 \mathrm{~cm} /$ tahun, akan tetapi karang ini juga cepat rusak karena struktur kerangkanya yang rapuh dan tidak tahan terhadap tekanan lingkungan seperti arus, gelombang, dan sedimentasi yang tinggi. Sebagai fast growing species seharusnya jenis karang Acropora mampu bertahan dan mendominasi terumbu karang di kedalaman 3 meter ke atas (Rani et al., 2004). Menurut Suharsono (1984), karang non- Acropora merupakan karang keras low growth species (spesies dengan kecepatan pertumbuhan lambat) yang pertumbuhannya hanya $1 \mathrm{~cm} /$ tahun. 


\section{KESIMPULAN}

Persentase tutupan karang keras di setiap stasiun adalah sebagai berikut, stasiun 1 (satu) 22,00\% berada pada kondisi rusak, stasiun 2 (dua) 7,67\% berada pada kondisi rusak, stasiun 3 (tiga) $6,00 \%$ berada pada kondisi rusak, dan stasiun 4 (empat) 46,67\%, berada pada kondisi sedang. Dari keempat stasiun tersebut dapat disimpulkan bahwa kondisi karang keras di perairan Bulutui masuk dalam kategori rusak dengan presentase $20,58 \%$, Nilai tersebut menunjukkan bahwa kondisi terumbu karang Perairan Bulutui berada dalam kondisi rusak, dan berada pada kategori buruk.

Total frekuensi kemunculan karang batu pada stasiun I sebanyak 66 kali dan didominasi oleh coral submassive (CS), Pada stasiun II total frekuensi kemunculan karang keras sebanyak 23 kali dan didominasi oleh coral massive (CM), pada stasiun III total frekuensi kemunculan karang keras sebanyak 18 dan didominasi oleh coral foliose (CF), selanjutnya pada stasiun IV total frekuensi kemunculan karang keras sebanyak 140 kali dan didominasi oleh coral foliose (CF).

\section{DAFTAR PUSTAKA}

Allen, G., R. Steene, P. Humann, N. DeLoach. 2008. Reef Fish Identification Tropical Pacific. Odyssey Publishing. California. 188-189 hal.

Burke, L., K. Reytar, M. Spalding, and A. L. Perry. 2012. Reefs at Risk Revisited in the Coral Triangle. World Resources Institute. Washington DC.

Hadi, T.A., M. Abrar., Giyanto., B. Prayudha, O. Johan, A. Budiyanto, A.R. Dzumalek., L.O. Alifatri., S. Sulha., Suharsono. Status Terumbu Karang Indonesia 2019. 2020. Pusat Penelitian Oseangrafi - Lembaga
IImu Pengetahuan Indonesia. Jakarta. 86 hal.

Harborne, A.R., D.C. Afzal dan M.J. Andrews. 2001. Honduras: Caribbean Coast. Journal Marine Pollution Bulletin. 42(12):12211235.

Haris, A. 2008. Transplantasi Karang Acroporidae pada Substrat Alami. Jurnal Penelitian Perikanan dan Kelautan. 10(12):33-421.

Hill, J. And C . Wilkinson. 2004. Methods for Ecological Monitoring of Coral Reefs. A Resources for Managers. Australian Institute of Marine Science, Townville. 117 hal.

Luthfi, O. M. dan N. Nurmalasari. 2017. Pertumbuhan Karang Foliose (Daun) Leptoseris Yabei Pada Taman Karang Di Cagar Alam Pulau Sempu, Malang. Conference Paper. Marine Science University of Brawijaya. Malang.

Kambong, A.G., L. Dumanaw., R.T.H. Sorongan, R.M. Senduk., S. Tasidjawa., F. Setiawan., A. Mukminin. 2013. Inventarisasi Calon Kawasan Konservasi Perairan Di Minahasa Utara Tahun 2013. Wildlife Conservation Society. Manado. 70 hal.

Manembu, I.S., L. Adrianto, D.G. Bengen dan F. Yulianda, 2012. Distribusi Karang dan Ikan Karang di Kawasan Reef Ball Teluk Buyat Kabupaten Minahasa Tenggara. Jurnal Perikanan dan Kelautan Tropis. 8(1):28-32.

Manengkey, H.W.K. 2010. Kandungan Bahan Organik Pada Sedimen di Perairan Teluk Buyat dan Sekitarnya. Jurnal Perikanan dan Kelautan Tropis. 6(3):114-119. 
Manuputty, A.E.W., dan Djuwariah. 2009. Panduan Metode Point Intercept Transect (PIT) Untuk Masyarakat Studi Baseline Dan Monitoring Kesehatan Karang Di Lokasi Daerah Perlindungan Laut (DPL). COREMAP II - LIPI. Jakarta. 66 hal.

Rani, C., J. Jompa, Amiruddin. 2004. Pertumbuhan tahunan karang keras Porites lutea di Pulau Spermonde: hubungannya dengan suhu dan curah hujan. Jurnal Torani. 14(4):195-203.
Suharsono. 1984. Pertumbuhan Karang. Pusat Penelitian Biologi Laut. LON-LIPI. Jakarta.

Veron, J.E.N. 2000. Corals of the World. Australian Institute of Marine Sciences. Townsville, Australia.

Wilson R.J., A. Darmawan, J. Subijanto. 2009. Rancangan IImiah Jejaring Kawasan Konservasi Laut Yang Tangguh Di Ekoregion Sunda Kecil. Laporan akhir. Laporan TNC Indonesia marine program No. 2B/09. Bali. 27 hal. 